\title{
Intramuscular IL-12 Electrogene Therapy for Treatment of Spontaneous Canine Tumors
}

\author{
Maja Cemazar1, Gregor Sersa', Darja Pavlin² and Natasa Tozon ${ }^{2}$ \\ ${ }^{1}$ Institute of Oncology Ljubljana, Department of Experimental Oncology \\ ${ }^{2}$ University of Ljubljana, Veterinary Faculty Ljubljana, Clinic for Small \\ Animal Medicine and Surgery \\ Slovenia
}

\section{Introduction}

In the last two decades an enormous progress has been made in research of gene therapy, translating this new therapeutic approach from preclinical level to a large number of clinical trials, which presented encouraging results in treatment of a number of different diseases, from a single gene disorders to a more complex diseases, such as cancer. According to the Journal of Gene Medicine, at present more than 1400 human clinical trials investigating effects of gene therapy have been conducted, over $2 / 3$ for therapy of cancer (www.wiley.com/genmed/clinical). With the advances in the field of gene therapy, this new therapeutic tool is steadily gaining its acceptance also in clinical veterinary medicine. In the last decade, a number of gene therapy clinical trials have been conducted on companion animals, employing both viral and nonviral vectors and evaluating its effects primarily in oncologic, haematologic, musculoskeletal and cardiovascular diseases (Bergmann et al., 2003; Bodles-Brakhop et al., 2008; Dow et al., 2005; Draghia-Akli et al. 2002; Herzog et al., 2001; Huttinger et al., 2008; Jahnke et al., 2007; Kamstock et al., 2006; Kornegay et al., 2010; Ohshima et al., 2009; Pavlin et al., 2011; Siddiqui et al., 2007; Sleeper et al., 2010; Z. Wang et al., 2007). Such clinical trials on companion animals not only play an essential role for progress of veterinary medicine, but also provide invaluable data for human clinical research, which cannot be gained from strictly preclinical research on experimental animals. With gene therapy having versatile applications, different approaches have been developed, utilizing delivery of therapeutic genes into a variety of target tissues. The first reports on using skeletal muscle as a target for gene delivery have been published in the 1990's and since then, extensive evidence has been presented that skeletal muscle is a suitable target tissue for gene therapy (Wolff et al., 1990). The main advantages of skeletal muscle are high capacity of protein synthesis and post-mitotic status of muscle fibers which enable longlasting transgene expression. Muscle targeted transgene delivery can lead to either local intramuscular secretion or systemic delivery of transgene products, thus having potential for treatment of both muscular and non-muscular disorders. The clinical applications of muscle targeted gene therapy are mainly correction of gene deficits in the muscle tissue (e.g. muscle dystrophies), intravascular release of therapeutic proteins resulting in expansion of this therapy on systemic level (e.g.immunomodulation) and DNA vaccination against tumor antigens or infectious agents. Intramuscular gene therapy in veterinary medicine has already been successfully applied for a variety of indications in a number of different animal 
species, for example in cattle and sheep (Howell et al., 2008; Mena et al., 2001; Tollefsen et al., 2003), horses (Brown et al., 2008), pigs (Brown et al., 2004; Gravier et al., 2007) as well as cats (Brown et al., 2009; Ross et al., 2006; Walker et al, 2005) and dogs. In dogs mainly ex vivo delivery approach and viral vectors have been used in different disease models, primarily for treatment of hemophilia B, muscle dystrophies and in therapy of ischemic heart disease (Arruda et al. 2010; Banks \& Chamberlain, 2008; Dixon \& Spinale, 2009; Hasbrouck \& High, 2008; Haurigot et al., 2010; Herzog et al., 2001; Katz et al., 2010; Ohshima et al., 2009; L. Wang \& Herzog, 2005; Z. Wang et al., 2007, 2009).

The most straightforward introduction of foreign transgenes into skeletal muscle is simple intramuscular injection of naked plasmid DNA, which can result in a sustained transgene expression (Budker et al., 2000; Lu et al., 2003; Wolff et al., 1990). The main disadvantage of this method, which severely limits its therapeutic potential, is low transfection efficiency and pronounced variability of inter-individual levels of gene expression (Mir et al., 1999). Both described limitations of this gene delivery technique can be ameliorated by different methods, one of them being electroporation.

Electroporation is a physical method for delivery of various molecules into the cells by transiently increasing permeability of cell membrane with application of controlled external electrical field to the target cells (Neumann et al., 1982). It displays effectiveness for a broad spectrum of applications, in both in vitro and in vivo settings. In vitro it is already routinely used as a method for intracellular delivery of a variety of molecules, e. g. RNA, DNA, dyes, ions, chemotherapeutic drugs, etc. In vivo it has shown a great potential for two prospective therapeutic approaches in oncology, electrochemotherapy and electrogene therapy (EGT), both already used in clinical practice in both human and veterinary medicine (Cemazar et al., 2008; Daud et al. 2008; Kodre et al., 2005; Mir et al., 1998; Pavlin et al., 2011; Reed et al., 2010; Sersa et al., 2000; Tozon et al., 2001, 2005). This method of transgene delivery can be applied to almost any tissue in a living organism, with research focused primarily on tumor tissue, skin and skeletal muscle (Cemazar \& Sersa, 2007). Electroporation based transfection of skeletal muscle or muscle targeted EGT has been proven to be one of the most efficient and simple methods among different nonviral delivery methods currently under investigation (Cemazar \& Sersa, 2007; Gehl et al., 1999). It combines injection of therapeutic plasmid DNA into the muscle with subsequent electroporation of the target tissue, resulting in dramatically, up to 2000-times, increased long-term local gene expression lasting more than one year (Aihara \& Miyaziki et al., 1998; Mir et al., 1999; Tevz et al., 2008).

In the last few years, the number of reports on successful intramuscular EGT in dogs is steadily increasing. Therapeutic genes, delivered into canine skeletal muscle with this technique are genes encoding growth hormone releasing hormone (GHRH) (BodlesBrakhop et al., 2008; Brown et al., 2009; Draghia-Akli et al., 2002), human coagulation factor IX (hF.IX) (Fewell et al., 2001) and interleukin-12 (IL-12) (Pavlin et al., 2008). These studies showed a considerable clinical effect of intramuscular EGT in canine patients. GHRH EGT resulted in dramatically improved clinical condition of dogs with cancer, resulting in prolonged life span and improved quality of life (Bodles-Brakhop et al., 2008; Draghia-Akli et al., 2002). In dogs with chronic renal failure the same therapy improved kidney function and anemia associated with kidney disease, leading to overall improved health and survival rate (Brown et al., 2009). Intramuscular hF.IX EGT led to significant increase in levels of hF.IX in dogs, which can be predicted to have therapeutic effect in animal models of hemophilia B (Fewell et al., 2001). An important aspect of these studies is the fact that the procedure was successfully performed on both healthy and diseased dogs, demonstrating 
that even debilitated, cachectic and immunocompromised animals are capable of systemic shedding of transgenes resulting in clinical effect of intramuscularly delivered therapeutic genes.

IL-12 is a heterodimeric protein composed of two covalently linked subunits, a $35 \mathrm{kDa}$ light chain (also known as p35 or IL-12a) and a 40 kDa heavy chain (known as p40 or IL-12ß). The discovery of IL-12 in 1989 revealed its strong effect on both innate immune system through induction of IFN-y production from natural killer (NK) cells as well as on adaptive immune system through generation of cytotoxic T Lymphocytes (Kobayashi et al., 1989; Trinchieri et al., 1992). Based on these biological actions it was predicted that this cytokine is required for resistance to bacterial and intracellular parasites, as well as for the establishment of organspecific autoimmunity (Trinchieri, 2003) and was considered that it shows possible therapeutic potential for treatment of diseases, which would favorably respond to its immunomodulating actions. With the additional discovery of its antiangiogenic effects (Voest et al., 1995), IL-12 became one of the most promising cytokines for treatment of malignant diseases.

A model of mechanisms involved in the antitumor effects of IL-12 predict that IL-12 directly activates cells of the adaptive (CD4+ and CD8+ T cells) and innate arm of immunity by helping to prime $\mathrm{T}$ cells increasing their survival, enhancing $\mathrm{T}$ cell, and NK cell effector functions as well as promoting induction of IFN- $\gamma$ secretion. IFN- $\gamma$ in turn acts directly on tumor cells and other cell components within the tumor, by enhancing recognition of tumor cells by $\mathrm{T}$ cells through MHC class I processing and presentation and by modifications of extracellular matrix, which result in reduced antiangiogenesis and tumor invasion. The end result of these actions is impediment of tumor growth and ultimately eradication of the tumor. The first preclinical studies in the early 1990s with recombinant IL-12 protein in cancer treatment indeed showed its antitumor and antimetastatic activity (Brunda et al., 1993; Nastala et al., 1994). Unfortunately, potent antitumor effect established on preclinical level did not translate to clinical setting, demonstrating only limited therapeutic effect with serious toxic side-effects in the first clinical studies (Atkins et al., 1997). Therefore new therapeutic approaches for in vivo delivery of IL-12 have been investigated, with gene transfer of $I L-12$ introducing safer and more effective treatment method compared to systemic application of recombinant protein.

As one of therapeutic gene delivery methods, IL-12 EGT has been utilized in a number of different tumor models both on preclinical level and in clinical trials (Cemazar et al., 2010). Using electroporation, the therapeutic gene has been delivered into tumor tissue or skeletal muscle and EGT has been used either as a single therapy or in combination with other therapeutic genes and agents (e.g. $I L-18, I L-27$, herpes virus thymidine kinase, tetanus toxin fragment C) or different treatment methods, e.g. electrochemotherapy or radiotherapy (Cemazar et al., 2010; Kamensek \& Sersa, 2008). These studies established that IL-12 EGT shows remarkable local and systemic antitumor effects, including significant growth delay and even achieving complete long-term regression of treated tumors, induction of long-term antitumor immunity, antimetastatic activity and prolongation of survival in treated animals. Direct antitumor effect in established tumors is generally better achieved with local intratumoral delivery of therapeutic gene, whereas intramuscular delivery results especially in good antimetastatic activity (Hanna et al., 2001; Lee et al., 2003; Li et al., 2005; Lucas et al., 2002; Tevz et al., 2009).

In preclinical studies the murine tumor models, which favorably responded to IL-12 EGT, were melanoma (L.C. Heller \& R. Heller, 2010), lymphoma (Lee et al., 2003), soft tissue 
sarcoma (Pavlin et al., 2009; Tevz et al., 2009) and a variety of different carcinomas (Cemazar et al., 2010; L.C. Heller et al., 2005). In clinical settings, intratumoral IL-12 EGT has been successfully used both in humans (Daud et al., 2008), as well as dogs (Cutrera et al., 2008; Pavlin et al., 2011; Reed et al., 2010). In all of presently published studies in tumor-bearing dogs, EGT has been performed with intratumoral delivery of $I L-12$ either alone (Chuang et al., 2009; Pavlin et al., 2011), or in combination with electrochemotherapy with bleomycin (Cutrera et al, 2008; Reed et al., 2010). The only published intramuscular IL-12 EGT in dogs was performed on healthy experimental beagles (Pavlin et al., 2008), showing feasibility, efficacy and safety of this approach. However, similar approach to IL-12 gene therapy in tumor-bearing companion animals has not yet been described.

The aim of our study was to evaluate effects of intramuscular EGT with plasmid encoding human IL-12 in dogs with spontaneously occurring tumors. For this purpose, $1 \mathrm{mg}$ of plasmid encoding human IL-12 was injected into $\mathrm{m}$. semitendinosus of 6 patients with 4 different tumor types. Systemic transgene release and induction of IFN- $\gamma$ response was determined by repeated measurements of hIL-12 and canine IFN- $\gamma$ (cIFN- $\gamma$ ) in patients' sera. Possible side effects of the procedure were monitored with regular clinical examinations and determination of selected hematology and biochemistry parameters.

\section{Materials and methods}

\subsection{Animals}

All animals participating in this study were referred to the Clinic for small animal medicine and surgery, Veterinary faculty of Ljubljana, University of Ljubljana, Slovenia, for evaluation of different types of spontaneously occurring tumors. Prior to inclusion, written consent for participation in the study was obtained from the owners and the study was approved by the Ethical Committee at the Ministry of Agriculture, Forestry and Food of the Republic of Slovenia (approval No. 323-451/2004-9). Six dogs of five different breeds corresponded to the inclusion criteria, their age ranging from 3 - 13 years (Table 1 ). Inclusion criteria for the study comprised at least one cytologically or histologically confirmed tumor nodule, good general health status of the animal with the basic hematology and biochemistry profile within reference limits and normal renal and cardiovascular function. In these animals intramuscular EGT was performed either as an adjuvant therapy to conventional therapeutical procedures, specific for each tumor type or as single therapy in a patient, where other therapies were not possible or acceptable by the owner.

The study cohort comprised of three dogs with intermediately (i.e. grade II) (Figure 1) and poorly differentiated (i.e. grade III) (Figure 2) mast cell tumors (MCT) in different clinical stages, and one dog with each: pulmonary histiocytic sarcoma (PHS) (Figure 3), osteosarcoma (OSA) (Figure 4) and mammary adenocarcinoma (MAC) (Table 1).

One patient with MCT had metastatic disease involving local lymph nodes, and neither of patients had clinically detectable distant metastases. Two of the patients, one with MCT and one with mammary adenocarcinoma, had recurrent disease after marginal surgery. Histological or cytological diagnosis was established with examination of tumor biopsies and local lymph node fine needle aspiration in all tumors except OSA. Superficial tumors were measured in three perpendicular directions and their volume was calculated using the formula: $\mathrm{V}=\mathrm{a} \times \mathrm{b} \times \mathrm{c} \times \Pi / 6$. 


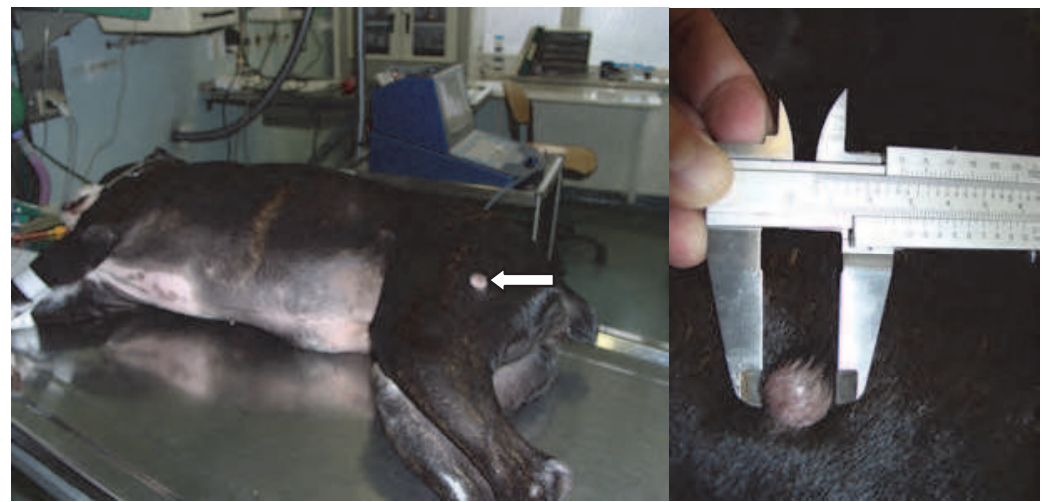

Fig. 1. Patient no. 2, German boxer with grade II MCT in the gluteal region, which was surgically removed and at the same time intramuscular EGT performed in the contralateral leg. Arrow indicats the position of the tumor.

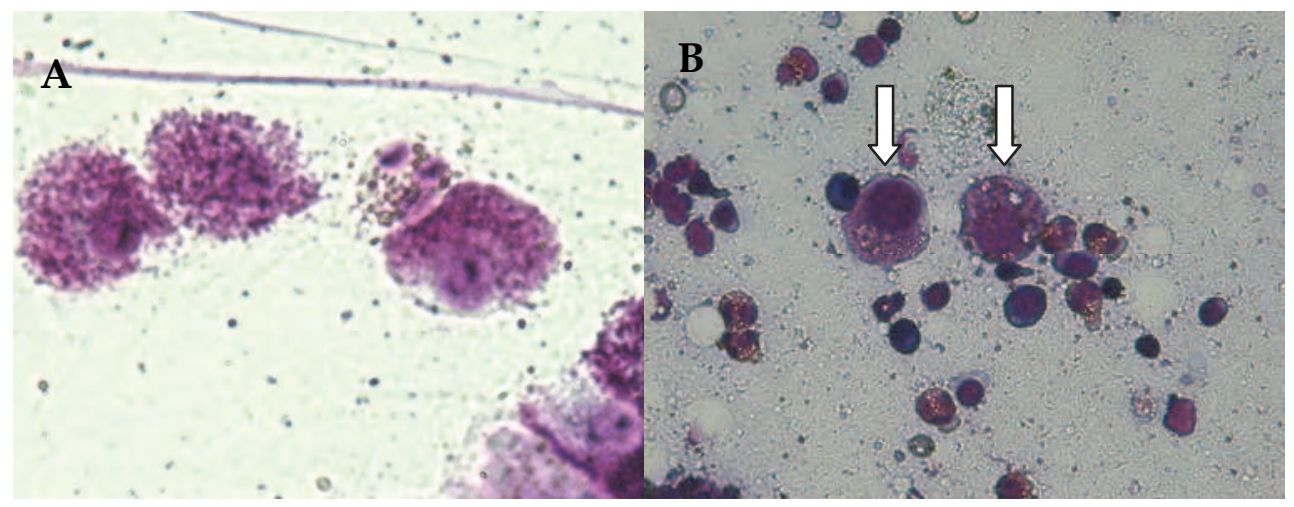

Fig. 2. Fine needle aspirate of poorly differentiated MCT (gradus III) in patient no. 3 (Giemsa stain). A: Tumor aspirate; B: Aspirate of prescapular lymph node with mast cell infiltrations (metastases of primary tumor in local lymph nodes) (arrows).

Before the treatment, staging of the disease according to modified WHO criteria in each patient was performed with clinical examinations, abdominal ultrasonography, thoracic radiography and basic bloodwork with biochemistry profile. Bloodwork included complete blood count with differential white blood cell count, performed with an automated laser hematology analyzer (Technicon $\mathrm{H}^{*} 1$, Bayer, Germany) with species-specific software $\left(\mathrm{H}^{*} 1\right.$ Multi-Species V30 Software). Determination of selected biochemistry parameters (serum concentrations of urea and creatinine and activity of serum alkaline phosphatase and alanine aminotransferase) was performed using automated chemistry analyzer Technicon RA-XT (Bayer, Germany). Basal determinations of serum concentrations of human IL-12 and canine IFN- $\gamma$ using ELISA kits (Human IL-12 Quantikine ELISA kit and Canine IFN- $\gamma$ Quantikine ELISA kit, respectively, both R\&D System, Minneapolis, MN, USA) were also performed. 


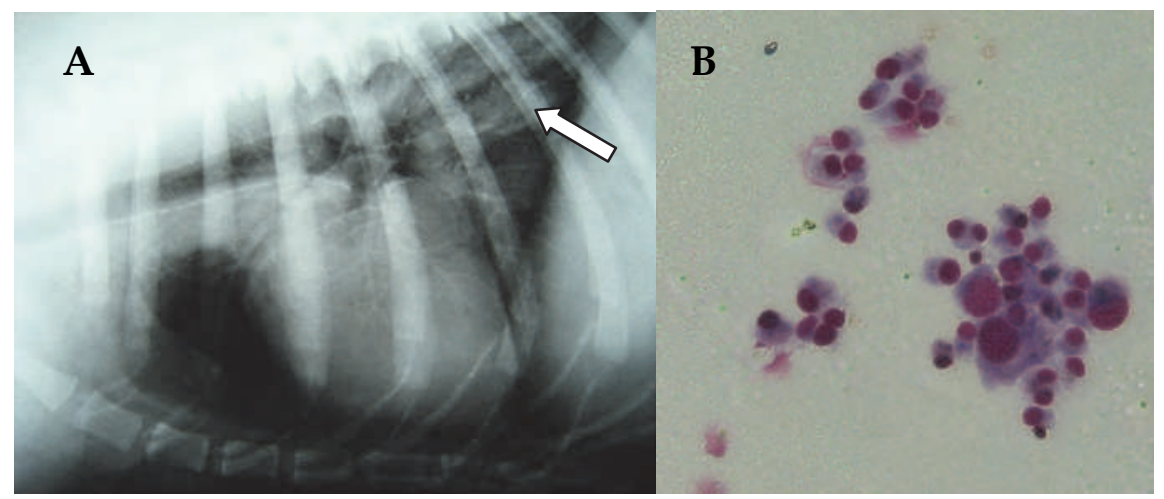

Fig. 3. Patient no. 4 with pulmonary histiocytic sarcoma. A: Thoracic radiograph of the patient depicting a solid mass in caudal lobe of the lungs (arrow); B: Fine needle aspirate of the tumor showing large round typically vacuolated histiocytic cells with high degree of anisokariosis (Giemsa stain; 400 times magnification).

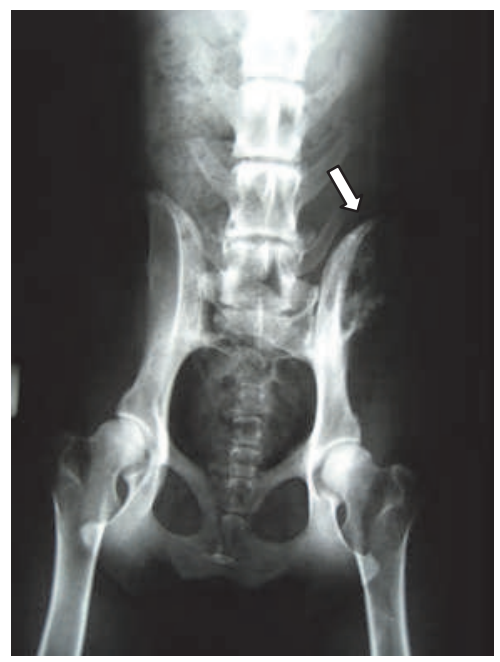

Fig. 4. Radiograph of pelvis in patient no. 5 showing predominantly osteolytic lesions on the iliac bone involving pars compacta (arrow), consistent with radiological presentation of osteosarcoma.

Each patient received one EGT treatment. In five of six treated animals, EGT was performed as an adjuvant therapy to conventional treatment procedures (Table 1). In all three dogs with $\mathrm{MCT}$, tumor nodules were marginally surgically removed prior to or concomitantly with EGT and two of these patients also received systemic chemotherapy, which consisted of either vincristine and methyprednisolone protocol $\left(0.5-0.7 \mathrm{mg} / \mathrm{m}^{2}\right.$ and $1 \mathrm{mg} / \mathrm{kg}$, respectively) or CCNU (lomustine, $60-90 \mathrm{mg} / \mathrm{m}^{2}$ ). In the patient with mammary adenocarcinoma, the tumor was surgically removed with marginal excision before performing EGT. The patient with pulmonary histiocytic sarcoma received one cycle of CCNU chemotherapy $\left(60 \mathrm{mg} / \mathrm{m}^{2}\right)$, 
applied two weeks after EGT. The only exception, in which EGT was performed as a single therapy was the dog with OSA in which location of the tumor (pelvis) precluded surgical treatment and the owner refused palliative radiotherapy.

\begin{tabular}{|c|c|c|c|c|c|c|}
\hline $\begin{array}{l}\text { Pt. } \\
\text { No. }\end{array}$ & Breed & $\begin{array}{c}\text { Age } \\
\text { (yrs)/ } \\
\text { Gender }\end{array}$ & Tumor type & $\begin{array}{l}\text { Tumor } \\
\text { location }\end{array}$ & $\begin{array}{l}\text { Clinical } \\
\text { stage }\end{array}$ & $\begin{array}{l}\text { Therapy (listed } \\
\text { chronologically) }\end{array}$ \\
\hline 1 & $\begin{array}{l}\text { German } \\
\text { boxer }\end{array}$ & $7 / \mathrm{M}$ & $\begin{array}{l}\text { Mast cell tumor } \\
\text { Gradus III }\end{array}$ & Front leg & II & $\begin{array}{l}\text { - Marginal surgery } \\
\text { - Systemic } \\
\text { chemotherapy } \\
\text { (V+M } 4 \text { cycles) } \\
\text { - EGT }\end{array}$ \\
\hline 2 & $\begin{array}{l}\text { German } \\
\text { boxer }\end{array}$ & $3 / F S$ & $\begin{array}{l}\text { Mast cell tumor } \\
\text { Gradus II }\end{array}$ & Hind leg & Ia & $\begin{array}{l}\text { - Surgery with } \\
\text { clear surgical } \\
\text { margins } \\
\text { concomitantly with } \\
\text { EGT } \\
\end{array}$ \\
\hline 3 & Lhasa-apso & 13/FS & $\begin{array}{l}\text { Mast cell tumor } \\
\text { Gradus III }\end{array}$ & $\begin{array}{c}\text { Neck } \\
\text { Metastases } \\
\text { in local } \\
\text { lymph } \\
\text { nodes } \\
\text { Recurrence } \\
\text { after } \\
\text { surgery } \\
\end{array}$ & IIIa & $\begin{array}{l}\text { - Marginal surgery } \\
\text { - EGT } \\
\text { - Systemic } \\
\text { chemotherapy } \\
\text { (V+M } 2 \text { cycle; } \\
\text { CCNU } 1 \text { cycles) }\end{array}$ \\
\hline 4 & $\begin{array}{c}\text { Bernese } \\
\text { mountain } \\
\text { dog }\end{array}$ & $6 / \mathrm{M}$ & $\begin{array}{l}\text { Pulmonary } \\
\text { histiocytic } \\
\text { sarcoma }\end{array}$ & Lungs & $\mathrm{N} / \mathrm{A}$ & $\begin{array}{l}-\mathrm{EGT} \\
\bullet \mathrm{CCNU} 1 \text { cycle }\end{array}$ \\
\hline 5 & $\begin{array}{l}\text { Doberman } \\
\text { Pinscher }\end{array}$ & 8/FS & Osteosarcoma & $\begin{array}{l}\text { Pelvis } \\
\text { (ilium) }\end{array}$ & $\mathrm{N} / \mathrm{D}$ & - EGT \\
\hline 6 & Crossbreed & $11 / \mathrm{FS}$ & $\begin{array}{c}\text { Mammary } \\
\text { adenocarcinoma }\end{array}$ & $\begin{array}{c}\text { Mammary } \\
\text { gland (D2-4) } \\
\text { Recurrence } \\
\text { after } \\
\text { surgery }\end{array}$ & IIIb & $\begin{array}{l}\text { - Surgery (partial } \\
\text { mastectomy) } \\
\text { - EGT }\end{array}$ \\
\hline
\end{tabular}

a - clinical stage according to modified WHO clinical staging system for mast cell tumors (Thamm \& Vail, 2007)

b - clinical stage according to Owen LN, Classification of tumors in domestic animals, Geneva, 1980, WHO

M: male, FS: spayed female, V+M: vincristine/methylprednisolone chemotherapy protocol, N/A: not applicable, N/D: not determined

Table 1. Summary of dogs' characteristics and histories

\subsection{Plasmid preparation}

The pORF-hIL-12 plasmid (InvivoGen, Toulouse, France), encoding human IL-12, was selected based on published data indicating that canine and human IL-12 share 
approximately $90 \%$ genetic identity based on amino acid sequence analysis (Buettner et al., 1998). Furthermore, it has already been shown that in in vitro settings, human IL-12 activates proliferation of canine peripheral blood mononuclear cells (PBMC), consequently triggering a number of immune responses in canine PBMCs (Phillips et al., 1999). The plasmid was prepared using the Qiagen Maxi Endo-Free kit (Qiagen, Hilden, Germany), according to manufacturer's instructions and diluted to concentration of $1 \mathrm{mg} / \mathrm{ml}$. Purified plasmid DNA was subjected to quality control and quantity determinations, performed by agarose gel electrophoresis and by means of spectrophotometry.

\subsection{Electrogene therapy procedure}

EGT was performed in the patients under general anesthesia, which was induced with propofol (Propoven $10 \mathrm{mg} / \mathrm{ml}$, Fresenius Kabi Austria GmbH, Graz, Austria) and maintained with isoflurane (Forane, Abbott Laboratories LTD, Queensborough, UK). During the anesthesia the animals were receiving Hartmann's solution (B. Braun Melsungen AG, Melsunen, Germany) at the rate of $10 \mathrm{ml} / \mathrm{kg}$ of bodyweight/h. Hair on the right femoral region was clipped and the area surgically prepared, followed by intramuscular injection of 1 $\mathrm{mg}$ of sterile solution of therapeutic plasmid into $\mathrm{m}$. semitendinosus using $1 \mathrm{ml}$ syringe with 22 $\mathrm{G}$ needle (Figure 5). The position of the needle was slightly changed during the emptying of syringe, allowing the content of syringe to infiltrate the target tissue more uniformly. Ten minutes later, electric pulses were applied to plasmid infiltrated muscle with electric pulses generator Cliniporator ${ }^{\mathrm{TM}}$ (IGEA s.r.l., Carpi, Italy), using intramuscularly placed needle electrodes N-18-4B (IGEA s.r.l., Carpi, Italy), which consist of 2 arrays, each composed of 4 electrodes with $4 \mathrm{~mm}$ distance between them. One HV pulse $(600 \mathrm{~V} / \mathrm{cm}, 100 \mu \mathrm{s})$ was delivered, followed by $4 \mathrm{LV}$ pulses $(80 \mathrm{~V} / \mathrm{cm}, 100 \mathrm{~ms}, 1 \mathrm{~Hz})$, with 1 second lag between the $\mathrm{HV}$ and LV pulses. Postsurgically, analgesia was provided to all dogs with single intravenous application of carprofen (Rimadyl, Pfizer Animal Health, Dundee, United Kingdom; 4mg/kg of bodyweight). When they fully recovered from anesthesia, they were released from the hospital. The treated femoral area was protected with suitable dressing in order to prevent licking and any possible contact of humans or animals with the electroporated region.

\subsection{Evaluation of response to the therapy}

Animals were examined 7, 14 and 28 days after EGT and monthly thereafter until any cytokine was detected in three consecutive samples. Each follow-up included the same diagnostic procedures as pre-therapy examination. At each examination, response to the therapy was evaluated with determination of serum concentrations of both previously mentioned cytokines, as described above, measurements of tumor nodules, where applicable and notification of possible side effects. For evaluation of local effects, measurements of tumor nodules, where applicable, were performed.

\subsection{Evaluation of possible side effects of the procedure}

The possible occurrence of local and systemic side effects was evaluated at each follow-up with clinical examination of the patients, assessment of electroporated area for appearance of any adverse effects to either plasmid solution or electroporation of the tissue (e.g. swelling, erythema, pain, secretions, tissue necrosis etc). Blood samples were collected at each follow-up for the same bloodwork as during the staging of the disease prior to EGT in order to evaluate possible systemic toxicity of the procedure. 


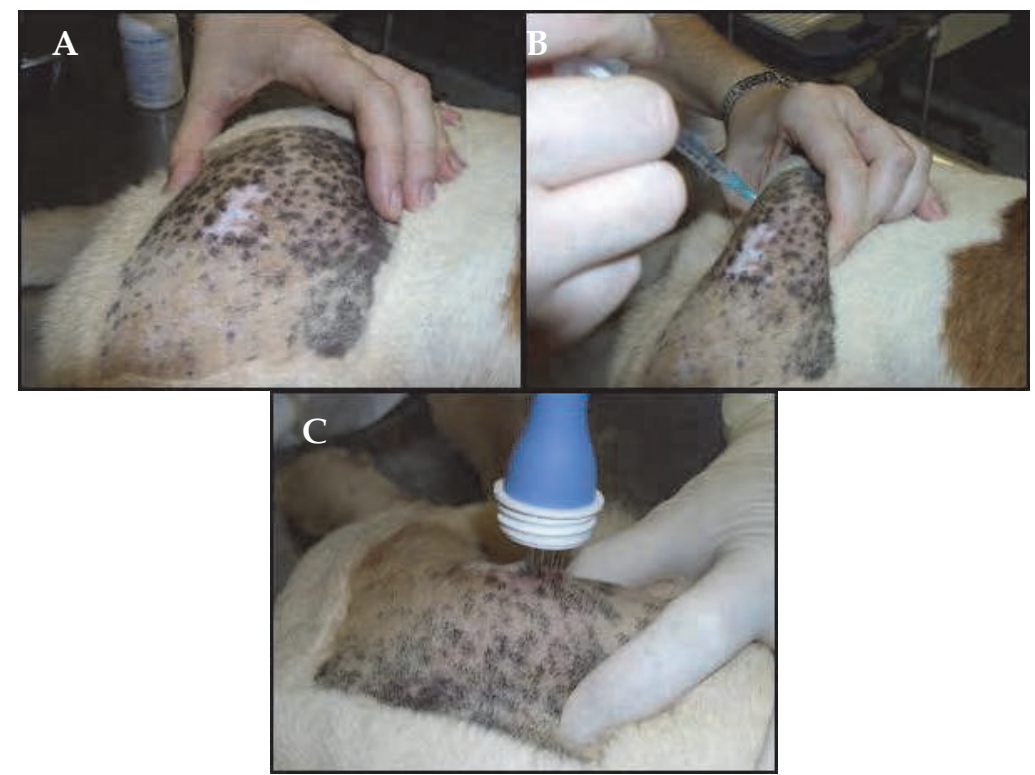

Fig. 5. Intramuscular EGT procedure. A: Surgically prepared femoral region; B: Intramuscular application of plasmid solution; C: Transcutaneous intramuscular placement of needle electrodes.

\section{Results}

\subsection{Response to the therapy}

In four out of six treated patients, serum concentrations of human IL-12 and/or canine IFN$\gamma$ were detected, among these responders were all three patients with MCT and the patient with PHS (Figure 6). Human IL-12 was detected in serum of a MCT patient 7 days after the procedure in concentration $17 \mathrm{pg} / \mathrm{ml}$. IFN- $\gamma$ was detected in single or multiple samples of all four mentioned patients, in concentrations ranging from 6.5 to $246.8 \mathrm{pg} / \mathrm{ml}, 4$ to 28 days after the EGT procedure (Table 2). None of the patients had any detectable hIL-12 or IFN- $\gamma$ in samples taken before the EGT procedures.

In these four patients, surprisingly long survival times after EGT were achieved (Table 2), even though intramuscular IL-12 EGT did not have any effect on volumes of measurable tumor nodules. The dog with recurrent grade III MCT and lymph node metastases (clinical stage III) and the dog with PHS received additional chemotherapy 2 weeks after EGT; however the chemotherapeutic protocols were shortly discontinued due to severe side effects both patients developed. Even though the delivered chemotherapy in these two patients was inadequate to be effective and result in potential systemic antitumor effect, the dog with MCT survived 6 and the dog with PHS 8 months after the EGT procedure. The other two patients with detected IL-12 and/or IFN- $\gamma$ had grade II and grade III MCTs. In the dog with grade II MCT (clinical stage I), the tumor nodule was marginally surgically removed and at the same time intramuscular IL-12 EGT performed, without any additional therapy. In the last dog, grade III MCT (clinical stage II) was treated with marginal excision and full chemotherapy with vincristine and methylprednisolone, followed by intramuscular 
IL-12 EGT. These two patients had complete response to the therapy without local recurrence or metastatic disease, surviving for over 4 and 3 years, respectively.

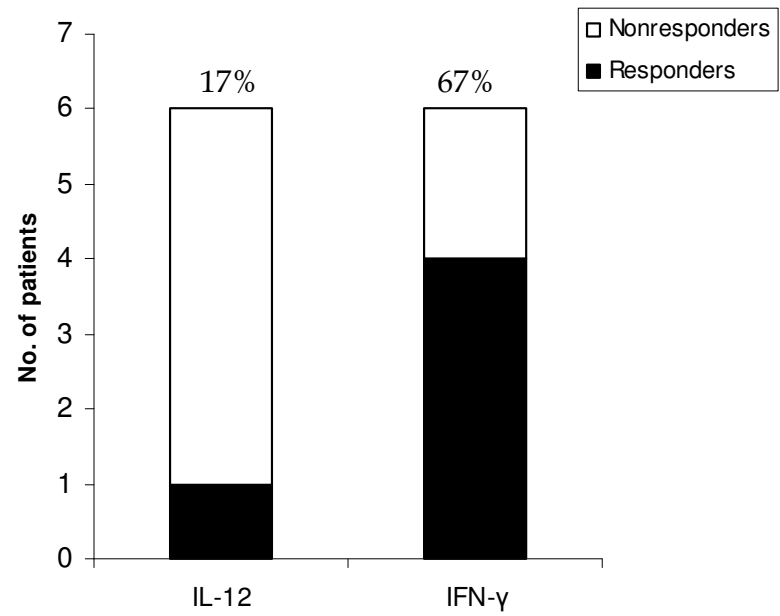

Fig. 6. Graph representing percentage of treated animals, which responded to intramuscular EGT with systemic release of either cytokine (i.e. responders) versus animals without systemically detectable cytokine (i.e. nonresponders).

\begin{tabular}{|c|c|c|c|c|c|c|}
\hline $\begin{array}{l}\text { Pt. } \\
\text { No. }\end{array}$ & Tumor type & $\begin{array}{c}\text { IL-12 } \\
(\mathrm{pg} / \mathrm{ml})\end{array}$ & 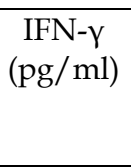 & $\begin{array}{l}\text { Timing of } \\
\text { sample } \\
\text { collection } \\
\text { after EGT }\end{array}$ & $\begin{array}{c}\text { Follow- } \\
\text { up after } \\
\text { EGT }\end{array}$ & $\begin{array}{c}\text { Response } \\
\text { to the } \\
\text { therapy }\end{array}$ \\
\hline 1 & $\begin{array}{l}\text { Mast cell tumor } \\
\text { Gradus III }\end{array}$ & $\begin{array}{c}17.0 \\
-\end{array}$ & $\begin{array}{c}- \\
246.8\end{array}$ & $\begin{array}{l}7 \text { days } \\
28 \text { days }\end{array}$ & $>3$ years & CR \\
\hline 2 & $\begin{array}{l}\text { Mast cell tumor } \\
\text { Gradus II }\end{array}$ & - & 6.5 & 7 days & $>4$ years & CR \\
\hline 3 & $\begin{array}{c}\text { Mast cell tumor } \\
\text { Gradus III }\end{array}$ & - & 80 & 7 days & 6 months & PD \\
\hline 4 & $\begin{array}{c}\text { Pulmonary } \\
\text { histiocytic } \\
\text { sarcoma }\end{array}$ & $\begin{array}{l}- \\
-\end{array}$ & $\begin{array}{c}37.1 \\
104.2\end{array}$ & $\begin{array}{l}7 \text { days } \\
14 \text { days }\end{array}$ & 8 months & SD \\
\hline 5 & Osteosarcoma & - & - & & $\begin{array}{c}5.5 \\
\text { months }\end{array}$ & SD \\
\hline 6 & $\begin{array}{c}\text { Mammary } \\
\text { adenocarcinoma }\end{array}$ & - & - & & 2 months & PD \\
\hline
\end{tabular}

Table 2. Response to the therapy in the treated patients. CR: complete response, PD: progressive disease, SD: stable disease

In the other two patients (OSA and recurrent extensive MAC), neither cytokine was detected in serum at any time point after surgery. The dog with OSA survived for 165 days without 
any additional treatment, except pharmacological pain management and was euthanized due to progression of pain, unresponsive to analgesic therapy, without any radiologically evident distant metastases. The patient with MAC was euthanized 2 months after EGT due to progression of the disease (growth of tumor).

\begin{tabular}{|c|c|c|c|c|c|c|c|c|c|}
\hline & $\begin{array}{c}\text { Before } \\
\text { EGT }\end{array}$ & Week 1 & Week 4 & Week 5 & $\begin{array}{c}\text { Week } \\
6\end{array}$ & Week 8 & Week 11 & $\begin{array}{c}\text { Week } \\
14\end{array}$ & $\begin{array}{c}\text { Ref. } \\
\text { values }\end{array}$ \\
\hline $\begin{array}{c}\text { Ther- } \\
\text { apy: }\end{array}$ & $\begin{array}{c}\text { V+M: } \\
\text { Cycle 1 }\end{array}$ & $\begin{array}{c}\text { V+M: } \\
\text { Cycle 2 }\end{array}$ & $\begin{array}{c}\text { V+M: } \\
\text { Stop }\end{array}$ & & $\begin{array}{c}\text { CCNU: } \\
\text { Cycle 1 }\end{array}$ & $\begin{array}{c}\text { CCNU: } \\
\text { Stop }\end{array}$ & & \\
\hline WBC & 13.64 & 21.41 & 15.84 & 3.29 & 16.25 & 19.78 & 13.51 & 12.96 & $6.0-18.0$ \\
\hline RBC & 8.45 & 6.85 & 6.12 & 6.55 & 7.10 & 6.35 & 6.89 & 6.59 & $5.1-8.5$ \\
\hline HCT & 0.57 & 0.47 & 0.44 & 0.47 & 0.52 & 0.47 & 0.51 & 0.48 & $\begin{array}{c}0.35- \\
0.55\end{array}$ \\
\hline Neutro & 8.43 & 16.48 & 12.27 & 1.29 & 12.31 & 17.25 & 10.48 & 12.2 & $3.0-11.8$ \\
\hline Urea & 10.2 & N/D & 9.2 & 12.1 & 11.9 & 13.2 & 8.03 & 10.5 & $3.0-12.5$ \\
\hline Crea & 107.4 & N/D & 90.6 & 111.3 & 114.9 & 109.5 & 96.9 & 118.1 & $\begin{array}{c}44.2- \\
132.6\end{array}$ \\
\hline SAP & 92.6 & 77.0 & 113.3 & N/D & 107.5 & 112.9 & 671.1 & 287.9 & $25-117$ \\
\hline ALT & 65.4 & 64.6 & 50.7 & N/D & 62.1 & 78.1 & 312.5 & 84.1 & $23-90$ \\
\hline
\end{tabular}

Table 3. Hematological and biochemistry results in the patient No. 3 with high grade MCT, receiving $I L-12$ EGT, followed by two different systemic chemotherapy protocols, applied only partially due to induction of marked side effects. Clinically relevant abnormalities in the bloodwork subsided after discontinuation of chemotherapy, demonstrating that the toxicity was caused by chemotherapy and not IL-12 EGT WBC: white blood cells, RBC: red blood cell, HCT: hematocrit, Neutro: neutrophils, Crea: creatinine, SAP: serum alkaline phosphatase, ALT: alanine aminotransferase, $\mathrm{V}+\mathrm{M}$ : vincristine/methylprednosolone chemotherapy protocol, N/D: not detected

\subsection{Side effects of the procedure}

In order to evaluate possible side effects at each follow-up, clinical examination as well as bloodwork with emphasis on kidney and liver function of patients was performed, due to known hepato- and nephrotoxicity of systemic recombinant IL-12 based therapy. We did not detect any side effects, which could be attributed to IL-12 toxicity, with hematological and biochemistry parameters staying within reference limits immediately after the procedure. In two of the patients marked hematological abnormalities were detected after induction of chemotherapy after EGT, which were attributed to the used chemotherapeutic agents, rather than EGT, since they were typical and well documented side effects of selected chemotherapy (i.e. leucopenia due to immunosuppression with vincristine and activation of serum alkaline phosphatase and alanin aminotrasferase due to hepatotoxicity of CCNU) (Table 3). In these two patients the abnormal values returned within the reference limits shortly after discontinuation of chemotherapy.

EGT procedure also did not cause any local side effects, for example swelling or inflammation of the electroporated area despite local invasiveness of the procedure, which was performed with intramuscularly placed needle electrodes (Figure 7). 


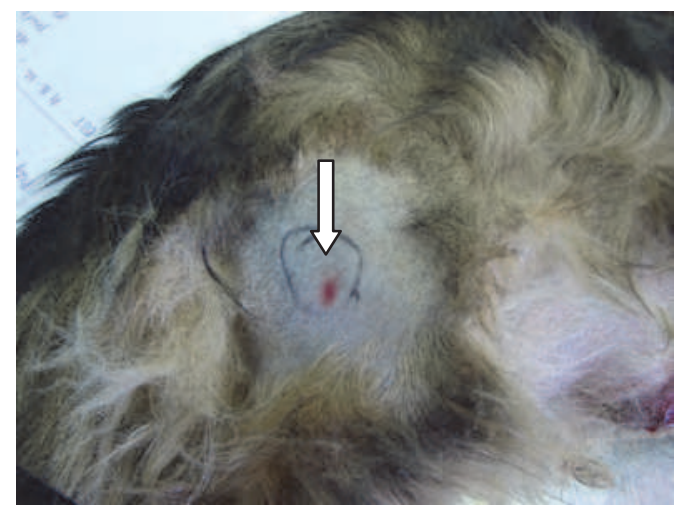

Fig. 7. The site of intramuscular EGT (arrow) in patient with mammary adenocarcinoma 2 days after the procedure without any signs of local side effects following invasive procedure

\section{Discussion}

Results of our study indicate that in canine cancer patients, intramuscular IL-12 EGT is a safe procedure, which can result in systemic shedding of human IL-12 and possibly trigger IFN- $\gamma$ response in treated patients, leading to prolonged disease free period and survival of treated animals.

In all of our patients, EGT was performed with a single intramuscular application of $1 \mathrm{mg}$ of therapeutic plasmid encoding human IL-12, followed by delivery of one high voltage pulse and four low voltage pulses. Four out of six patients responded to the therapy with systemically detectable human IL-12 and/or IFN- $\gamma$ concentrations. Systemic release of encoded transgene products in sufficient concentrations to elicit biological effect was already demonstrated after intramuscular EGT with different therapeutic genes in dogs (Brown et al., 2009; Draghia-Akli et al., 2002; Fewell et al., 2001; Pavlin et al., 2008; Tone et al., 2004). In preclinical studies, intramuscular IL-12 EGT displayed systemic antitumor effect due to systemic release of IL-12 and IFN- $\gamma$ in several tumor models (Hanna et al., 2001; Lee et al., 2003; Lucas et al., 2002, 2003; Tevz et al., 2009; Zhu \& Li, 2008). Compared to these studies, we achieved relatively low systemic concentrations of IL-12, whereas the serum concentrations of IFN- $\gamma$ were comparable to concentrations achieved in experimental animals (Lucas et al., 2002; Tevz et al., 2009).

It is possible that more pronounced response to the therapy with higher systemic cytokine concentrations in treated patients could be achieved with application of either higher plasmid dose or with more repetitions of EGT procedure. Even though Fewell and colleagues achieved systemic release of therapeutic concentration of human coagulation factor IX with a single intramuscular EGT of therapeutic plasmid, extremely high dose of therapeutic plasmid had to be delivered, even up to $3 \mathrm{mg}$ of plasmid $/ \mathrm{kg}$ of bodyweight (Fewell et al., 2001). Similarly, different experiments showed that in large animals the level of systemically secreted transgene product is dose and volume dependent with increased transgene expression correlating with increase in plasmid dose and volume until a certain saturating dose (Khan et al., 2003). On the other hand, in studies where therapeutic plasmid encoding GHRH was used, biological effects were achieved after single EGT with plasmid doses as low as $10-100 \mu \mathrm{g}$ of plasmid per kg of bodyweight (Brown et al., 2009; Draghia- 
Akli et al., 2002; Tone et al., 2004). As established in preclinical research, size and construction of plasmid plays an important role in effectiveness of electroporation-based delivery of DNA in vivo (Cemazar \& Sersa, 2007). This fact could in part explain such striking differences in plasmid doses, which were needed in different studies on dogs to exert systemically detectable transgene product release. Therefore in the future, optimization of dose with dose escalation studies should be attempted for each therapeutic plasmid.

Another possible improvement of systemic transgene release could be in multiple consecutive repetitions of EGT procedure. Several previous studies on different animal tumor models demonstrated, that more than one either intratumoral or intramuscular application of plasmid encoding IL-12 is necessary to achieve adequate therapeutic response in treated animals, even without systemically detectable IL-12 concentrations (Heinzerling et al., 2001; L.C. Heller et al., 2006; Lucas \& R. Heller, 2003; Tevz et al., 2009). For example in melanoma tumor model significantly better therapeutic response was achieved with increasing the number of intratumoral applications or with addition of intramuscular gene delivery (Lucas \& R. Heller, 2003). Similarly, four consecutive intramuscular IL-12 EGTs resulted in a significantly better systemic release of IL-12, compared to a single EGT procedure (Tevz et al., 2009).

Another possible explanation for nonresponders is that the timing of the samples collections was not optimal, since the samples were collected every 1 to 2 weeks in the first month and monthly thereafter. According to published literature, the time of the highest systemic release of IL-12 and IFN- $\gamma$ achieved after intramuscular IL-12 EGT is greatly variable. In different studies, the highest serum concentration of IL-12 was achieved between 4 and 17 days after EGT procedure, followed by the elevation of IFN- $\gamma$ serum level with approximately 4-5 days delay (Lucas et al., 2002; Tevz et al., 2009). Kinetics of systemic IL-12 release varies even within the same species. In mice intramuscular EGT with the same plasmid dose results in significantly different systemic transgene release depending on strain of treated animals (Tevz et al., 2009). For example, in C57Bl/6 strain, serum concentration of IL-12 reached peak on day 6 (Tevz et al., 2009) or day 10 (Lucas et al., 2002) after EGT and abruptly declined to approximately half of peak concentration in the next few days. On the other hand, in A/J mice strain, serum concentration of IL-12 reached plateau by day 6 , which lasted until approximately day 14 , followed by a slow decline. Even more surprising is the fact, that in $\mathrm{C} 57 \mathrm{Bl} / 6$ strain approximately three-times higher serum concentrations of IL-12 were achieved compared to A/J strain. The underlying mechanisms responsible for these discrepancies in transgene expression are not yet explained. Therefore even in a relatively homogenous group of experimental animals, determination of optimal serum collection timing is not as straightforward. Based on these findings, in such a heterogenic group as dogs, greatly varying in size and other physical attributes, a more thorough examination of cytokine release after intramuscular EGT should be attempted. Data on kinetics of transgene release in dogs after intramuscular IL-12 EGT would be helpful for clinical application to determine the best time intervals for treatment repetitions in each individual patient in order to achieve the maximum therapeutic effect.

In our study, intramuscular EGT did not exert such pronounced local antitumor effect on treated tumors compared to direct intratumoral IL-12 EGT (Chuang et al. 2009; Pavlin et al., 2011). In four of our patients, where tumors were not surgically removed and the size of intact tumors could be repeatedly measured, there was no regression in tumor size after performed EGT. In comparison, with intratumoral IL-12 EGT volumes of treated canine 
mast cell tumors reduced significantly by over 50\% (Pavlin et al., 2011) and even complete remissions were achieved in experimentally induced transmissible veneral tumors in dogs (Chuang et al., 2009). This discrepancy in antitumor effectiveness of intratumoral versus intramuscular IL-12 EGT has already been shown in experimentally induced tumors in preclinical studies. Usually, intratumoral IL-12 EGT results in better direct antitumor effect, demonstrated as growth delay and reduction of treated tumors' size, compared to intramuscular route of gene delivery (Lucas et al., 2002, 2003). On the other hand, intramuscular IL-12 EGT exhibits pronounced antimetastatic effect with high systemic concentrations of IL-12 and stable induction of IFN-Y response (Hanna et al., 2001; Tevz et al., 2009). With intramuscular route of therapeutic gene delivery, relatively low proportion of complete regressions is achieved, typically around $15-40 \%$, depending on model of treated tumor (Lee et al., 2003; Lucas et al., 2003; Tevz et al., 2009), whereas in some of the reported studies, complete response with intramuscular IL-12 EGT was not achieved (Hanna et al., 2001). In comparison, intratumoral IL-12 EGT generally results in approximately 60$80 \%$ complete response rate in treated tumors (L.C. Heller et al., 2006; Lucas et al., 2003), even reaching 100\% curability (Pavlin et al., 2009). Based on results of preclinical work it can be concluded that the main advantage of intramuscular IL-12 EGT lies in its systemic effects, namely antimetastatic activity and consequently prolongation of treated animals survival time (Lee et al., 2003; Lucas et al., 2002; Tevz et al., 2009; Zhu \& Li, 2008).

Even though we treated a relatively small number of animals, their survival times after EGT were longer compared to survival times associated with specific tumor types from literature review. For example, the patient with PHS was euthanized over 8 months after EGT and a single application of CCNU due to progression of clinical signs, namely dispnoa and exercise intolerance. According to the literature, median survival time for dogs with PHS, treated with full CCNU chemotherapy (four consecutive applications every 3 weeks), is 96106 days (Fulmer \& Maudlin, 2007; Rassnick et al., 2010; Skropuski et al., 2007). In this patient, CCNU therapy was discontinued after one application due to pronounced hepatotoxicity, therefore probably exerting only negligible therapeutic effect. The patient with OSA survived 5.5 months, whereas reported median survival time for dog with OSA without any treatment is 1 - 3 months (Selvarajah et al., 2009). In three patients with higher grade MCTs, relatively long survival times were achieved. In canine MCT, survival strongly correlates with histological grade of the tumor and clinical stage of the disease (Patnaik et al., 1984), with very high recurrence rate after surgical therapy in more aggressive higher grade tumors (Fox, 2002; Thamm \& Vail, 2007). The patient with grade III MCT in clinical stage III of the disease with recurrent growth of tumor tissue immediately after marginal resection of MCT and metastases in local lymph nodes survived for 6 months after EGT before being euthanized due to progression of the disease. Two weeks after EGT, consecutively two different systemic chemotherapies were started, each discontinued shortly after induction due to severe side-effects, therefore none of the chemotherapy protocol was administered long enough to reach any therapeutic potential. In comparison to these three patients, veterinary literature reports approximately $30 \%$ local recurrence of incompletely excised grade II MCT (Thamm \& Vail, 2007) and only 7\% partial response rate, without any complete responses, to full chemotherapy protocol utilizing vincristine (McCaw et al., 1997). For patients with grade III MCT, median survival time of 3 months after surgery without any additional therapy is reported (Thamm \& Vail, 2007).

In preclinical studies intramuscular IL-12 EGT conveyed in successful transgene expression and systemic release of significant concentrations of IL-12, therefore raising concerns 
regarding safety of this therapeutic approach, based on described toxicity of systemic application of recombinant IL-12. It has been established that systemic recombinant IL-12 therapy can exhibit serious adverse effects, including elevated body temperature, headaches, nausea and vomiting, nephro- and hepatotoxicity (Leonard et al., 1997) and application of high dose of rIL-12 was linked with temporary immunosuppression (neutropenia, lymphopenia, thrombocytopenia and anemia) (Motzer et al., 1998), which would not be favorable for effective immunotherapy. Therefore monitoring of renal and hepatic function in patients receiving any IL-12 based therapy is strongly recommended. These adverse effects are presumably due to toxicity of IFN- $\gamma$ response induced by circulating IL-12 (Car et al., 1999; Leonard et al., 1997; Ryffel, 1996). Toxic side effects in human patients appeared when serum concentration of IFN- $\gamma$ exceeded $6.0 \mathrm{ng} / \mathrm{ml}$ (Leonard et al., 1997), whereas experimental animals tolerated serum concentrations as high as 300 $\mathrm{ng} / \mathrm{ml}$ without any severe adverse reactions (Leonard et al., 1997). A comprehensive study of intratumoral IL-12 EGT toxicity has been conducted, with evaluation of changes in weight and blood biochemistry and haematology parameters, as well as histopatological examination of several different tissues of treated animals (L.C. Heller et al., 2006). Even though a pronounced antitumor effect was achieved on melanoma tumor model, no significant side effects of the procedure were observed (L.C. Heller et al., 2006). Although sporadically, significant abnormalities in bloodwork were detected, they were clinically irrelevant for the treated animals. The only histopathologic abnormality was late-onset inflammation associated with the kidney without any biochemical markers of decreased kidney function. Nevertheless, these findings did not reflect in any impairment of general health of treated animals. Nevertheless, in this study no systemically detectable concentrations of either IL-12 or IFN- $\gamma$ were achieved. Therefore its conclusions can not directly demonstrate safety of intramuscular IL-12 EGT as well, since intramuscular route of therapeutic gene administration can result in significant systemic concentrations of both IL12 and IFN- $\gamma$. In preclinical studies, side-effects of the procedure were not so thoroughly investigated, however, available data show that intramuscular IL-12 EGT, compared to intratumoral, can exhibit more pronounced, but still tolerable side effects, mainly transient significant reduction of bodyweight at the highest serum concentrations of IL-12 and IFN- $\gamma$ (Tevz et al., 2009).

Clinical status of all animals enrolled in our study remained unaltered for the first 8 weeks after the EGT procedure. In the two patients with progressive disease (one patient with MCT and a patient with MAC), deterioration of general health was observed after 6 and 2 months, respectively, which reflected the increased tumor burden and was not a consequence of any toxic effects of the procedure. Hematology as well as biochemistry parameters of collected blood samples remained mostly within reference limits throughout the observation period. Few clinically significant alterations were observed in two patients receiving systemic chemotherapy. In the patient with PHS elevation of serum activities of enzymes ALT and SAP, which are biomarkers of liver function, was observed. However, this change occurred a week after induction of chemotherapy with CCNU, which exhibits known hepatotoxicity (Kristal et al., 2004). In the first two weeks after EGT, before the chemotherapy was started, no abnormalities in bloodwork were observed in this patient, despite detecting elevated serum levels of IFN-ץ in blood samples collected 7 and 14 days after EGT. Furthermore, the increase in activities of both enzymes was only transient and their values normalized immediately after cessation of systemic chemotherapy. Similarly, transient haematological abnormalities were detected in the patient with MCT, receiving first immunosuppressive chemotherapy consisting 
of vincristine and methylprednisolone and later CCNU. Bloodwork alterations were related to toxicity of these chemotherapy protocols, since they were displayed only after induction of chemotherapy and not around the time, when elevated levels of IFN- $\gamma$ in patient's serum was detected. Other patients with systemically detectable IFN- $\gamma$, even as high as $246.8 \mathrm{pg} / \mathrm{ml}$, did not display any abnormalities in their bloodwork assays. Therefore we can conclude, that the observed hepatotoxicity and immunosuppression were due to pharmacological agents rather than a side effect of $I L-12$ gene therapy.

\section{Conclusion}

In conclusion, the results of this study indicate, that intramuscular IL-12 EGT in dogs with spontaneously occurring tumors, is a feasible, simple and safe procedure, which exerts systemic transgene release of IL-12 and induction of IFN- $\gamma$ response in treated animals, making it promising treatment modality in veterinary medicine. In the future, refinement of treatment protocols in different canine tumors should be performed, with respect to investigating kinetics of cytokine release, defining optimal plasmid dose, number of treatment repetitions and effect of combination with other treatment protocols (e.g. local intratumoral plasmid delivery or electrochemotherapy) in order to achieve effective longterm antitumor effect in canine cancer patients.

\section{Acknowledgement}

The authors acknowledge the financial support of the state budget by Slovenian Research Agency (Projects No. P3-0003, P4-0053 and J3-2277). We would also like to thank dr. Tanja Plavec, dr. Tanja Svara and Estera Pogorevc for their help with cytology samples and radiographs of the patients.

\section{References}

Aihara, H. \& Miyaziki, J. (1998). Gene transfer into muscle by electroporation in vivo, Nat Biotechnol, Vol.16, No.9, (September 1998), pp. 867-870

Arruda,V.R., Stedman, H.H., Haurigot, V., Buchlis, G., Baila, S., Favaro, P., Chen, Y., Franck, H.G., Zhou, S., Wright, J.F., Couto, L.B., Jiang, H., Pierce, G.F., Bellinger, D.A., Mingozzi, F., Nichols, T.C., High, K.A. (2010). Peripheral transvenular delivery of deno-associated viral vectors to skeletal muscle as a novel therapy for hemophilia B, Blood, Vol.115, No.23, (June 2010), pp. 4678-4688

Atkins, M.B., Robertson, M.J., Gordon, M., Lotze, M.T., DeCoste, M., DuBois, J.S., Ritz, J., Sandler, A.B., Edington, H.D., Garzone, P.D., Mier, J.W., Canning, C.M., Battiato, L., Tahara, H., Sherman, M.L. (1997). Phase I evaluation of intravenous recombinant human interleukin 12 in patients with advanced malignancies, Clin Cancer Res., Vol.3, No.3, (March 1997), pp.409-417

Banks, G.B. \& Chamberlain, J.S. (2008). The value of mammalian models for duchenne muscular dystrophy in developing therapeutic strategies, Curr Top Dev Biol, Vol.84, pp. $431-453$

Bergman, P.J., McKnight, J., Novosad, A., Charney, S., Farrelly, J., Craft, D., Wulderk, M., Jeffers, Y., Sadelain, M., Hohenhaus, A.E., Segal, N., Gregor, P., Engelhorn, M., Riviere, I., Houghton, A.N., Wolchok, J.D. (2003). Long-term survival of dogs with 
advanced malignant melanoma after DNA vaccination with xenogeneic human tyrosinase: a phase I trial, Clin Cancer Res, Vol.9, No.4, (April 2003), pp.1284-1290

Bodles-Brakhop, A.M., Brown, P.A., Pope, M.A., Draghia-Akli, R. (2008). Double-blinded, Placebo-controlled plasmid GHRH trial for cancer-associated anemia in dogs, Mol Ther, Vol.16, No.5, (May 2008), pp.862-870

Brown, P.A., Bodles-Brakhop, A., Draghia-Akli, R. (2008). Plasmid growth hormone releasing hormone therapy in healthy and laminitis-afflicted horses-evaluation and pilot study, J Gene Med, Vol.10, No.5, (May 2008), pp.564-574

Brown, P.A., Bodles-Brakhop, A.M., Pope, M.A., Draghia-Akli, R. (2009). Gene therapy by electroporation for the treatment of chronic renal failure in companion animals, BMC Biotechnol, (January 2009), 9:4

Brunda, M.J., Luistro, L., Warrier, R.R. et al. (1993). Antitumor and antimetastatic activity of interleukin 12 against murine tumors, J Exp Med, Vol.178, No.4, (October 1993), pp.1223-1230

Budker, V., Budker, T., Zhang, G., Subbotin, V., Loomis, A., Wolff, J.A. (2000). Hypothesis: naked plasmid DNA is taken up by cells in vivo by a receptor-mediated process, $J$ Gene Med, Vol.2, No.2, (March 2000), pp. 76-88

Buettner, M., Belke-Louis, G., Rziha, H.J., McInnes, C., Kaaden, O.R. (1998). Detection, cDNA cloning and sequencing of canine interleukin 12, Cytokine, Vol.10, No.4, (April 1998), pp.241-248

Car, B.D., Eng, V.M., Lipman, J.M., Anderson, T.D. (1999). The toxicology of interleukin-12: a review. Toxicol Pathol, Vol.27, No.1, (January 1999), pp.58-63.

Cemazar, M. \& Sersa, G. (2007). Electrotransfer of therapeutic molecules into tissues. Curr Opin Mol Ther, Vol.9, No.6, (December 2007), pp.554-562

Cemazar, M., Tamzali, Y., Sersa, G., Tozon, N., Mir, L.M., Miklavcic, D., Lowe, R., Teissie, J. (2008). Electrochemotherapy in veterinary oncology, J Vet Intern Med, Vol.22, No.4, (July 2008), pp.826-831

Cemazar M, Jarm T, Sersa G. Cancer electrogene therapy with interleukin-12, Curr Gene Ther, Vol.10, No.4, pp.300-311

Cutrera, J., Torrero, M., Shiomitsu, K., Mauldin, N., Li, S. (2008). Intratumoral bleomycin and IL-12 electrochemogenetherapy for treating head and neck tumors in dogs, Methods Mol Biol, Vol.423, pp.319-325

Daud, A.I., DeConti, R.C., Andrews, S., Urbas, P., Riker, A.I., Sondak, V.K., Munster, P.N., Sullivan, D.M., Ugen, K.E., Messina, J.L., Heller, R. (2008). Phase I trial of interleukin-12 plasmid electroporation in patients with metastatic melanoma J Clin Oncol, Vol.26, No.36, (December 2008), pp.5896-5903

Dixon, J.A. \& Spinale, F.G. (2009). Large animal models of heart failure: a critical link in he translation of basic science to clinical practice, Circ Heart Fail, Vol.2, No.3, (May 2009), pp. 262-271

Dow, S., Elmslie, R., Kurzman, I., MacEwen, G., Pericle, F., Liggitt, D. (2005). Phase I study of liposome-DNA complexes encoding the interleukin-2 gene in dogs with osteosarcoma lung metastases, Hum Gene Ther, Vol.16, No.8, (August 2005), pp.937-946

Draghia-Akli, R., Hahn, K.A., King, G.K., Cummings, K.K., Carpenter, R.H. (2002). Effects of plasmid-mediated growth hormone-releasing hormone in severely debilitated dogs with cancer, Mol Ther, Vol.6, No.6, (December 2002), pp.830-836 
Fewell, J.G., MacLaughlin, F., Mehta, V., Gondo, M., Nicol, F., Wilson, E., Smith, L.C. (2001). Gene therapy for the treatment of hemophilia B using PINC-formulated plasmid delivered to muscle with electroporation, Mol Ther, Vol.3, No.4, (April 2001), pp.574-583

Fox, L.E. (2002). Mast Cell Tumors. In: Cancer in dogs and cats: medical and surgical management, 2nd ed., Morrison, W.B., ed., pp.451-460, Teton NewMedia, Jackson Hole, ISBN: 1-893441-47-4

Fulmer, A.K. \& Mauldin, G.E. (2007). Canine histiocytic neoplasia: An overview, Can Vet J, Vol.48, No.10, (October 2007), pp.1046-1050

Gehl, J., Sorensen, T.H., Nielsen, K., Raskmark, P., Nielsen, S.L., Skovsgaard, T., Mir, L.M. (1999). In vivo electroporation of skeletal muscle: threshold, efficacy and relation to electric field distribution, Biochim Biophys Acta, Vol.1428, No.2-3, (August 1999), pp.233-240

Gravier, R., Dory, D., Laurentie, M., Bougeard, S., Cariolet, R., Jestin, A. (2007). In vivo tissue distribution and kinetics of a pseudorabies virus plasmid DNA vaccine after intramuscular injection in swine, Vaccine, Vol.25, No.39-40, (September 2007), pp.6930-6938

Hanna, E., Zhang, X., Woodlis, J., Breau, R., Suen, J., Li, S. (2001). Intramuscular electroporation delivery of IL-12 gene for treatment of squamous cell carcinoma located at distant site, Cancer Gene Ther, Vol.8, No.3, (March 2001), pp.151-157

Hasbrouck, N.C. \& High, K.A. (2008). AAV-mediated gene transfer for the treatment of hemophilia B: problems and prospects, Gene Ther, Vol.15, No.11, (June 2008), pp.870-875

Haurigot, V., Mingozzi, F., Buchlis, G., Hui, D.J., Chen, Y., Basner-Tschakarjan, E., Arruda, V.R., Radu, A., Franck, H.G., Wright, J.F., Zhou, S., Stedman, H.H., Bellinger, D.A., Nichols, T.C., High, K.A. (2010). Safety of AAV factor IX peripheral transvenular gene elivery to muscle in hemophilia B dogs, Mol Ther, Vol.18, No.7, (July 2010), pp.1318-1329

Heinzerling, L.M., Feige, K., Rieder, S., Akens, M.K., Dummer, R., Stranzinger, G., Moelling, K. (2001). Tumor regression induced by intratumoral injection of DNA coding for human interleukin 12 into melanoma metastases in gray horses, J Mol Med, Vol.78, No.12, pp.692-702

Heller, L.C., Merkler, K., Westover, J., Cruz, Y., Coppola, D., Benson, K., Daud, A., Heller, R. (2006). Evaluation of toxicity following electrically mediated interleukin-12 gene delivery in a B16 mouse melanoma model, Clin Cancer Res, Vol.12, No.10, (May 2006), pp.3177-3183

Heller, L.C. \& Heller, R. (2010). Electroporation gene therapy preclinical and clinical trials for melanoma, Curr Gene Ther, Vol.10, No.4, (August 2010), pp.312-317

Herzog, R.W., Mount, J.D., Arruda, V.R., High, K.A., Lothrop, C.D. Jr. (2001). Muscledirected gene transfer and transient immune suppression result in sustained partial correction of canine hemophilia B caused by a null mutation, Mol Ther, Vol. 4, No.3., (September 2001), pp.192-200

Howell, J.M., Walker, K.R., Davies, L., Dunton, E., Everaardt, A., Laing, N., Karpati, G. (2008). Adenovirus and adeno-associated virus-mediated delivery of human myophosphorylase cDNA and LacZ cDNA to muscle in the ovine model of 
McArdle's disease: expression and re-expression of glycogen phosphorylase, Neuromuscul Disord, Vol.18, No.3, (March 2008), pp.248-258

Hüttinger, C., Hirschberger, J., Jahnke, A., Köstlin, R., Brill, T., Plank, C., Küchenhoff, H., Krieger, S., Schillinger, U. (2008). Neoadjuvant gene delivery of feline granulocytemacrophage colony-stimulating factor using magnetofection for the treatment of feline fibrosarcomas: a phase I trial, J Gene Med, Vol.10, No.6, (June 2008), pp.655667

Jahnke, A., Hirschberger, J., Fischer, C., Brill, T., Köstlin, R., Plank, C., Küchenhoff, H., Krieger, S., Kamenica, K., Schillinger, U. (2007). Intra-tumoral gene delivery of feIL2, feIFN-gamma and feGM-CSF using magnetofection as a neoadjuvant treatment option for feline fibrosarcomas: a phase-I study, J Vet Med A Physiol Pathol Clin Med, Vol.54, No.10, (December 2007), pp.599-606

Kamensek, U. \& Sersa, G. (2008). Targeted gene therapy in radiotherapy, Radiol Oncol, Vol.42, No.3, pp.115-135

Kamstock, D., Guth, A., Elmslie, R., Kurzman, I., Liggitt, D., Coro, L., Fairman, J., Dow, S. (2006). Liposome-DNA complexes infused intravenously inhibit tumor angiogenesis and elicit antitumor activity in dogs with soft tissue sarcoma, Cancer Gene Ther, Vol.13, No.3, (March 2006), pp.306-317

Katz, M.G., Swain, J.D., White, J.D., Low, D., Stedman, H., Bridges, C.R. (2010). Cardiac gene therapy: optimization of gene delivery techniques in vivo, Hum Gene Ther, Vol.21, No.4, (April 2010), pp.371-380

Khan, A.S., Smith, L.C., Abruzzese, R.V., Cummings, K.K., Pope, M.A., Brown, P.A., Draghia-Akli, R. (2003). Optimization of of electroporation parameters for the intramuscular delivery of plasmids in pigs. DNA Cell Biol, Vol.22, No.12, (December 2003), pp.807-814

Kobayashi, M., Fitz, L., Ryan, M., Hewick, R.M., Clark, S.C., Chan, S., Loudon, R., Sherman, F., Perussia, B., Trinchieri, G. (1989). Identification and purification of natural-killer cell stimulatory factor (NKSF), a cytokine with multiple biologic effects on humanlymphocytes, J Exp Med, Vol.170, No.3, (September 1989), pp.827-845

Kodre, V., Cemazar, M., Pecar, J., Sersa, G., Cor, A., Tozon, N. (2009). Electrochemotherapy compared to surgery for treatment of canine mast cell tumours, In Vivo, Vol.23, No.1, (January 2009), pp.55-62

Kornegay, J.N., Li, J., Bogan, J.R., Bogan, D.J., Chen, C., Zheng, H., Wang, B., Qiao, C., Howard, J.F. Jr., Xiao, X. (2010). Widespread muscle expression of an AAV9 human mini-dystrophin vector after intravenous injection in neonatal dystrophin-deficient dogs, Mol Ther, Vol.18, No.8, (August 2010), pp.1501-1508

Kristal, O., Rassnick, K.M., Gliatto, J.M., Northrup, N.C., Chretin, J.D., Morrison-Collister, K., Cotter, S.M., Moore, A.S. (2004). Hepatotoxicity associated with CCNU (lomustine) chemotherapy in dogs, J Vet Intern Med, Vol.18, No.1, (January 2004), pp.75-80

Lee, S.C., Wu, C.J., Wu, P.Y., Huang, Y.L., Wu, C.W., Tao, M.H. (2003). Inhibition of established subcutaneous and metastatic murine tumors by intramuscular electroporation of the interleukin-12 gene, J Biomed Sci, Vol.10, No.1, (January 2003), pp.73-86

Leonard, J.P., Sherman, M.L., Fisher, G.L., Buchanan, L.J., Larsen, G., Atkins, M.B., Sosman, J.A., Dutcher, J.P., Vogelzang, N.J., Ryan, J.L. (1997). Effects of single-dose 
interleukin-12 exposure on interleukin-12-associated toxicity and interferongamma production, Blood, Vol.90, No.7, (October 1997), pp.2541-2548

Li, S., Zhang, L., Torrero, M., Cannon, M., Barret, R. (2005). Administration route- and immune cell activation-dependant tumor eradication by IL-12 electrotransfer, Mol Ther, Vol.12, No.5, (November 2005), pp.942-949

Lu, Q., Bou-Gharion, G., Partridge, T.A. (2003). Non-viral gene delivery in skeletal muscle: a protein factory, Gene Ther, Vol.10, No.2, (January 2003), pp.131-142

Lucas, M.L., Heller, L., Coppola, D., Heller, R. (2002). IL-12 plasmid delivery by in vivo electroporation for the successful treatment of established subcutaneous B16.F10 melanoma, Mol Ther, Vol.5, No.6, (June 2002), pp.668-675

Lucas, M.L. \& Heller, R. (2003). IL-12 gene therapy using an electrically mediated nonviral approach reduces metastatic growth of melanoma, DNA and Cell Biol, Vol.22, No.12, (December 2003), pp.755-763

McCaw, D.L., Miller, M.A., Bergman, P.J., Withrow, S.J., Moore, A.S., Knapp, D.W., Fowler, D., Johnson, J.C. (1997). Vincristine therapy for mast cell tumors in dogs, J Vet Intern Med, Vol.11, No.6, (November 1997), pp. 375-378

Mena, A., Andrew, M.E., Coupar, B.E. (2001). Rapid dissemination of intramuscularly inoculated DNA vaccines, Immunol Cell Biol, Vol.79, No.1, (February 2001), pp.87-89

Mir, L.M., Glass, L.F., Sersa, G., Teissié, J., Domenge, C., Miklavcic, D., Jaroszeski, M.J., Orlowski, S., Reintgen, D.S., Rudolf, Z., Belehradek, M., Gilbert, R., Rols, M.P., Belehradek, J. Jr., Bachaud, J.M., DeConti, R., Stabuc, B., Cemazar, M., Coninx, P., Heller, R. (1998). Effective treatment of cutaneous and subcutaneous malignant tumours by electrochemotherapy, Br J Cancer, Vol.77, No.12, (June 1998), pp.23362342

Mir, L.M., Bureau, M.F., Gehl, J., Rangara, R., Rouy, D., Caillaud, J.M., Delaere, P., Branellec, D., Schwartz, B., Scherman, D. (1999). High-efficiency gene transfer into skeletal muscle mediated by electric pulses, Proc Natl Acad Sci U S A, Vol.96, No.8, (April 1999), pp.4262-4267

Motzer, R.J., Rakhit, A., Schwartz, L.H., Olencki, T., Malone, T.M., Sandstrom, K., Nadeau, R., Parmar, H., Bukowski, R. (1998). Phase I trial of subcutaneous recombinant human interleukin-12 in patients with advanced renal cell carcinoma, Clin Cancer Res, Vol.4, No.5, (May 1998), pp.1183-1191

Nastala, C.L., Edington, H.D., McKinney, T.G., Tahara, H., Nalesnik, M.A., Brunda, M.J., Gately, M.K., Wolf, S.F., Schreiber, R.D., Storkus, W.J. (1994). Recombinant IL-12 administration induces tumor regression in association with IFN-gamma production, J Immunol, Vol.153, No.4, (August 1994), pp.1697-1706

Neumann, E., Schaefer-Ridder, M., Wang, Y., Hofschneider, P.H. (1982). Gene transfer into mouse lyoma cells by electroporation in high electric fields, EMBO, Vol.1, No.7, pp.841-845

Ohshima, S., Shin, J.H., Yuasa, K., Nishiyama, A., Kira, J., Okada, T., Takeda, S. (2009). Transduction efficiency and immune response associated with the administration of AAV8 vector into dog skeletal muscle, Mol Ther, Vol.17, No.1, (Jauary 2009), pp.73-80

Patnaik, A.K., Ehler, W.Y., MacEwen, E.G. (1984). Canine cutaneous mast cell tumors: morphological grading and survival in 83 dogs, Vet Pathol, Vol.21, No.5, (september 1984), pp.469-474 
Pavlin, D., Tozon, N., Sersa, G., Pogacnik, A., Cemazar, M. (2008). Efficient electrotransfection into canine muscle, Technol Cancer Res Treat, Vol.7, No.1, (February 2008), pp. 45-54

Pavlin, D., Cemazar, M., Kamensek, U., Tozon, N., Pogacnik, A., Sersa, G. (2009). Local and systemic antitumor effect of intratumoral and peritumoral IL-12 electrogene therapy on murine sarcoma, Cancer Biol Ther, Vol.8, No.22, (November 2009), pp.2114-2122

Pavlin, D., Cemazar, M., Cor, A., Sersa, G., Pogacnik, A., Tozon, N. (2011). Electrogene therapy with interleukin-12 in canine mast cell tumors, Radiol Oncol, Vol.45, No.1, (March 2011), pp.31-39

Phillips, B.S., Padilla, M.L., Dickerson, E.B., Lindstrom, M.J., Helfand, S.C. (1999). Immunostimulatory effects of human recombinant interleukin-12 on peripheral blood mononuclear cells from normal dogs, Vet Immunol Immunopathol, Vol.70, No.3-4, (September 1999), pp.189-201

Ross, C.J., Twisk, J., Bakker, A.C., Miao, F., Verbart, D., Rip, J., Godbey, T., Dijkhuizen, P., Hermens, W.T., Kastelein, J.J., Kuivenhoven, J.A., Meulenberg, J.M., Hayden, M.R. (2006). Correction of feline lipoprotein lipase deficiency with adeno-associated virus serotype 1-mediated gene transfer of the lipoprotein lipase S447X beneficial mutation, Hum Gene Ther, Vol.17, No.5, (May 2006), pp.487-499

Rassnick KM, Moore AS, Russell DS, Northrup NC, Kristal O, Bailey DB, Flory AB, Kiselow MA, Intile JL. Phase II, open-label trial of single-agent CCNU in dogs with previously untreated histiocytic sarcoma, J Vet Intern Med, Vol.24, No.6, (November 2010), pp.1528-1531

Ryffel, B. (1996). Unanticipated human toxicology of recombinant proteins, Arch Toxicol Suppl, Vol.18, pp.333-341

Selvarajah, G.T., Kirpensteijn, J., van Wolferen, M.E., Rao, N.A., Fieten, H., Mol, J.A. (2009). Gene expression profiling of canine osteosarcoma reveals genes associated with short and long survival times, Molecular Cancer, No. 8, (September 2009), pp.72

Sersa, G., Stabuc, B., Cemazar, M., Miklavcic, D., Rudolf, Z. (2000). Electrochemotherapy with cisplatin: clinical experience in malignant melanoma patients, Clin Canc Res, Vol.6, No.3, (March 2000), pp.863-867

Siddiqui, F., Li, C.Y., Larue, S.M., Poulson, J.M., Avery, P.R., Pruitt, A.F., Zhang, X., Ullrich, R.L., Thrall, D.E., Dewhirst, M.W., Hauck, M.L. (2007). A phase I trial of hyperthermia-induced interleukin-12 gene therapy in spontaneously arising feline soft tissue sarcomas, Mol Cancer Ther, Vol.6, No.1, (January 2007), pp.380-389

Skorupski, K.A., Clifford, C.C., Paoloni, M.C, Lara-Garcia, A., Barber, L., Kent, M.S., LeBlanc, A.K., Sabhlok, A., Mauldin, E.A., Shofer, F.S., Couto, C.G., Sørenmo, K.U. (2007). CCNU for the treatment of dogs with histiocytic sarcoma, J Vet Intern Med, Vol21, No.1, (January 2007), pp. 121-126

Sleeper, M.M., Bish, L.T., Sweeney, H.L. (2010). Status of therapeutic gene transfer to treat canine dilated cardiomyopathy in dogs, Vet Clin North Am Small Anim Pract, Vol.40, No.4, (July 2010), pp.717-724

Tevz, G., Kranjc, S., Cemazar, M., Kamensek, U., Coer, A., Krzan, M., Vidic, S., Pavlin, D., Sersa, G. (2009). Controlled systemic release of interleukin-12 after gene electrotransfer to muscle for cancer gene therapy alone or in combination with 
ionizing radiation in murine sarcomas, J Gene Med, Vol.11, No.12, (December 2009), pp.1125-1137

Thamm, D.H. \& Vail, D.M. (2007). Mast Cell Tumors, In: Withrow and MacEwen's small animal clinical oncology, Withrow, S.J. \& Wail, D.M., eds., pp.402-416, Saunders, St. Louis, ISBN: 9780-7216-0558-6

Tollefsen, S., Vordermeier, M., Olsen, I., Storset, A.K., Reitan, L.J., Clifford, D., Lowrie, D.B., Wiker, H.G., Huygen, K., Hewinson, G., Mathiesen, I., Tjelle, T.E. (2003). DNA injection in combination with electroporation: a novel method for vaccination of farmed ruminants, Scand J Immunol, Vol.57, No.3, (March 2003), pp.229-238

Tone, C.M., Cardoza, D.M., Carpenter, R.H., Draghia-Akli, R. (2004). Long-term effects of plasmid-mediated growth hormone releasing hormone in dogs, Cancer Gene Ther, Vol.11, No.5, (May 2004), pp.389-396

Tozon, N., Sersa, G., Cemazar, M. (2001). Electrochemotherapy: potentiation of local antitumour effectiveness of cisplatin in dogs and cats, Anticancer Res, Vol.21, No.4A, (July 2001), pp.2483-2488

Tozon, N., Kodre, V., Sersa, G., Cemazar, M. (2005). Effective treatment of perianal tumors in dogs with electrochemotherapy, Anticancer Res, Vol.25, No.2A, (March 2005), pp.839-845

Trinchieri, G., Wysocka, M., D'Andrea, A., Rengaraju, M., Aste-Amezaga, M., Kubin, M., Valiante, N.M., Chehimi, J. (1992). Natural killer cell stimulatory factor (NKSF) or interleukin-12 is a key regulator of immune response and inflammation, Prog Growth Factor Res, Vol.4, No.4, pp.355-368

Trinchieri G. Interleukin-12 and the regulation of innate resistance and adaptive immunity, Nat Rev Immunol, Vol.3, No.2, (February 2003), pp.133-146

Voest, E.E., Kenyon, B.M., O'Reilly, M.S., Truitt, G., D'Amato, R.J., Folkman, J. (1995). Inhibition of angiogenesis in vivo by interleukin 12, J Natl Cancer Inst, Vol.87, No.8, (April 1995), pp. 581-586

Walker, M.C., Mandell, T.C., Crawford, P.C., Simon, G.G., Cahill, K.S., Fernandes, P.J., MacLeod, J.N., Byrne, B.J., Levy, J.K. (2005). Expression of erythropoietin in cats treated with a recombinant adeno-associated viral vector, Am J Vet Res, Vol.66, No.3, (March 2005), pp.450-456

Wang, L. \& Herzog, R.W. (2005). AAV-mediated gene transfer for treatment of hemophilia, Curr Gene Ther, Vol.5, No.3, (June 2005), pp.349-360

Wang, Z., Kuhr, C.S., Allen, J.M., Blankinship, M., Gregorevic, P., Chamberlain, J.S., Tapscott, S.J., Storb, R. (2007). Sustained AAV-mediated dystrophin expression in a canine model of Duchenne muscular dystrophy with a brief course of immunosuppression, Mol Ther, Vol.15, No.6, (June 2007), pp.1160-1166

Wang, Z., Chamberlain, J.S., Tapscott, S.J., Storb, R. (2009). Gene therapy in large animal models of muscular dystrophy, ILAR J, Vol.50, No.2, pp.187-198

Wolff, J.A., Malone, R.W., Williams, P., Chong, W., Acsadi, G., Jani, A., Felgner, P.L. (1990). Direct gene transfer into mouse muscle in vivo, Science, Vol.247, (March 1990), pp.1465-1468

Zhu, S. \& Li, S. (2008). Systemic IL-12 gene therapy for treating malignancy via intramuscular electroporation, Methods Mol Biol, No.423, pp.327-337 


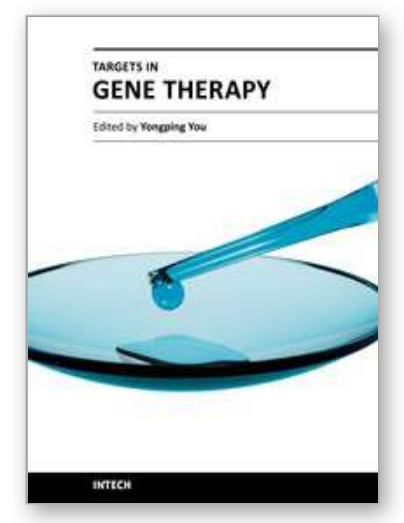

\author{
Targets in Gene Therapy \\ Edited by Prof. Yongping You
}

ISBN 978-953-307-540-2

Hard cover, 436 pages

Publisher InTech

Published online 23, August, 2011

Published in print edition August, 2011

This book aims at providing an up-to-date report to cover key aspects of existing problems in the emerging field of targets in gene therapy. With the contributions in various disciplines of gene therapy, the book brings together major approaches: Target Strategy in Gene Therapy, Gene Therapy of Cancer and Gene Therapy of Other Diseases. This source enables clinicians and researchers to select and effectively utilize new translational approaches in gene therapy and analyze the developments in target strategy in gene therapy.

\title{
How to reference
}

In order to correctly reference this scholarly work, feel free to copy and paste the following:

Maja Cemazar, Gregor Sersa, Darja Pavlin and Natasa Tozon (2011). Intramuscular IL-12 Electrogene Therapy for Treatment of Spontaneous Canine Tumors, Targets in Gene Therapy, Prof. Yongping You (Ed.), ISBN: 978-953-307-540-2, InTech, Available from: http://www.intechopen.com/books/targets-in-genetherapy/intramuscular-il-12-electrogene-therapy-for-treatment-of-spontaneous-canine-tumors

\section{INTECH}

open science | open minds

\section{InTech Europe}

University Campus STeP Ri

Slavka Krautzeka 83/A

51000 Rijeka, Croatia

Phone: +385 (51) 770447

Fax: +385 (51) 686166

www.intechopen.com

\section{InTech China}

Unit 405, Office Block, Hotel Equatorial Shanghai

No.65, Yan An Road (West), Shanghai, 200040, China 中国上海市延安西路65号上海国际贵都大饭店办公楼 405 单元

Phone: +86-21-62489820

Fax: $+86-21-62489821$ 
(C) 2011 The Author(s). Licensee IntechOpen. This chapter is distributed under the terms of the Creative Commons Attribution-NonCommercialShareAlike-3.0 License, which permits use, distribution and reproduction for non-commercial purposes, provided the original is properly cited and derivative works building on this content are distributed under the same license. 